\title{
SIMULATION BASED ANALYSIS ON THE EFFECTS OF ORIENTATION ON ENERGY PERFORMANCE OF RESIDENTIAL BUILDINGS IN GHANA
}

\author{
C. Koranteng and E.G. Abaitey \\ Department of Architecture, \\ Kwame Nkrumah University of Science and Technology, Kumasi, Ghana
}

\begin{abstract}
Since the energy crisis in 2007, energy performance of buildings is gradually becoming an issue in Ghana. The authors of this paper used simulation as a tool to analyse three conventional residential building types, in order to see the effects of orientation on energy performance, specifically on cooling loads. The three building types; a single storey square block, a single storey rectangular block and a two storey square block with different thermal properties were modelled and simulated. Alternate north angles were used and results compared for the best orientation resulting in minimum cooling loads in the climatic context of Kumasi, Ghana. The results on the rectangular building indicated the best orientation as being north and south. No particular orientation could be recommended for the single and two storey building (with square plans) and this showed that the influence of other factors such as windows, configuration and function of spaces, and building mass directly affected cooling loads and eventually orientation.
\end{abstract}

Keywords: Simulation, Orientation, Energy Performance, Cooling Load, North Angle

\section{INTRODUCTION}

Orientation, a key issue in energy performance and thermal comfort in sustainable architecture, has not been given much attention in environmental design. New construction projects and renovated buildings in Ghana show the lack of energy efficiency in design. This is seen in the rampant use of curtain walls, sliding windows and air conditioners in most buildings with disregard to orientation. With energy consumption in housing increasing as compared to the production, it is necessary to adapt sustainable design methods to reduce the demand on energy, especially for cooling, and to promote an environmentally sound tropical architecture for residential buildings in Ghana.

New and renovated buildings in Ghana are now characterised by the use of air-conditioners, sliding windows and are oriented anyhow. These building elements and design strategies have a direct link to efficiency and energy consumption. To have energy efficient buildings, there is the need to orientate our buildings in the direction where less energy would be spent in maintaining thermal comfort. In passive solar architecture, southward orientation is recommended over east-west, where energy losses of $30 \%$ are to be expected (Wagner et al. 1980). 
As countries like Ghana struggle to pursue meaningful development, there is the need for policies to support the process of development. Presently, there are no energy efficiency codes in the building sector which would regulate issues such as the energy consumption levels of building types, thermal resistance properties of building components, etc.

From a historical perspective, the ancient Greeks and Romans oriented their buildings to the south to take advantage of the winter sun. Their buildings also functioned well in summer, when temperatures could reach tropical levels like in Ghana as they provided cool and comfortable conditions (Lechner 2001).

In warm and humid regions, solar radiation is diffused and intense. Humidity and rainfall values are high, sometimes reaching saturation point. Comfort is achieved through evaporative cooling in naturally ventilated buildings. However, most buildings are being air-conditioned and the trend is not expected to decrease. With the architecture of the tropics covering nearly $40 \%$ of the world's surface and the majority of countries in these regions in the process of developing, their energy demand will most probably increase likewise.

Comfort in many buildings is achieved through mechanical means. Generally, mechanical cooling uses six times the amount of energy required for e.g., heating and it is therefore prudent to be energy conscious in the design of buildings in tropical countries (Lauber 2005). Buildings should therefore be oriented appropriately, function well through passive means and if need be, be supported through mechanical means to achieve comfort.

In his book, "Architectural Design for Tropical Regions", Salmon (1999), has the following views on passive designs: "Buildings should be able to respond to changes in climate by rejection of solar heat and have the thermal integrity to maintain internal comfort, despite the influence of climatic forces acting on the building envelope. In addition, the building should be able to retain cool, in order to maintain comfort. In this regard, the exact solar orientation is not critical." He however establishes that, analysis of sun paths and wind directions has shown that elongated buildings should be oriented to the south. In addition, the best orientation for wind is the southwest whiles a compromise of $22.5^{\circ}$ (south-southwest) should give the best orientation.

Lauber (2005) made a recommendation which was somehow different from that made by Salmon. He proposes $+/-30^{\circ}$ from the prevailing wind direction as the best orientation for buildings in warm and humid countries. This will mean a building with the elongated side oriented $15^{\circ}$ west of south and $15^{\circ}$ south of west. The latter option is not ideal since it has all the areas of the façade exposed to the morning and evening sun. Lauber (2005) further states that the shell of air-conditioned buildings must be insulated, windproof and airtight. This suggests an orientation away from the prevailing wind direction. He however did not suggest a precise direction for air-conditioned buildings.

According to Szokolay (2004), orientation can also be a function of aspect ratio, which has a great influence on the thermal performance of the building. Aspect ratio is the length of an elongated side of the building, usually the north and south, in relation to the shorter sides, east and west. A recommended ratio is between 1.3 and 2.0, depending on temperature and radiation conditions. Szokolay (2004) shows that for naturally ventilated buildings, major openings that are on the northern and southern elongated walls should face within $45^{\circ}$ of the prevailing wind direction. This is $15^{\circ}$ more than what Lauber (2005) suggested. On the other hand, this implies an optimum orientation of the elongated sides facing north or south, and a thermally inappropriate direction of openings facing the western sun.

Ferstl (2003), proposed elongated orientation of buildings towards the north and south. For energy efficiency purposes, he further recommends heavy weight materials on the eastern and western walls to restrict the flow of solar heat during the day. This design consideration 
is to be supported by vegetation on the east and western sides.

Koenigsberger et al. (1974), suggest the orientation of buildings in warm and humid climates in such a position that they can utilise the prevailing air movements. This will suggest an orientation to the southwest and northeast with some degrees of unspecified freedom.

Gut et al. (1993), generally suggest the orientation towards the northern and southern slopes, since the eastern and western slopes comparatively receive more radiation. However, longshaped buildings should be arranged across prevailing wind directions. This implies the southwest and northeast direction. He continues to propose that for a compromise between sun and wind orientation, an analysis of the specific situation has to be done. The latter statement is more general and the designer has to rely on specific weather data for justification. He concludes with a general rule saying, "with lowrise buildings where the walls would not receive much radiation, orientation to the wind direction is more advisable."

Givoni (1981), has an interesting opinion to orientation. He generally takes components of the building and looks at their design, colour of façade, functions of rooms, day lighting, etc. He then suggests a $45^{\circ}$ of winds incidence on a wall (for naturally ventilated buildings) to provide satisfactory ventilation in warm and humid climates.

Szokolay (2004) and Givoni (1981) both proposed a $45^{\circ}$ degree of freedom from the prevailing wind direction. Lauber (2005) gave a range of $30^{\circ}$. However, they all seem to favour a north-south orientation when the issue is about elongated buildings. Their general perception with square buildings is the need for functional analysis of the spaces for justification of the orientation of the space.

Hawkes (1996), has grouped buildings into exclusive and selective modes. The exclusive mode has an automatically artificial environment. The shape is compact and tries to minimise the influence of the external environment, therefore, orientation is not important. The environment of the selective mode is controlled by automatic and manual means with a mixture of natural and artificial variables. The shape is dispersed and seeks to maximise the use of ambient energy. Orientation is an important factor in this mode. This implies that buildings in the exclusive mode are most likely to orient spaces anyhow and could have higher energy performance levels. Those in the selective mode would orientate spaces to the direction of prevailing winds; functions of spaces are important and could be a factor in the determination of the orientation.

Lechner (2001), uses the balance point temperature (BPT) to classify buildings. The BPT is the temperature below/above which heating/ cooling is required and it is a consequence of building design and function, but not climate.

Some of the knowledge behind the "building design and function" as the main dependency seems to be shared by Hawkes (1996) and Givoni (1981) even though their explanations are somewhat different. This depicts the closeness of orientation to the general form of a building and its effect on energy performance. On the other hand, if BPT is a function of temperature, then it should also be a function of orientation among other parameters.

According to Watson et al. (1983), the orientation of the building shell is important in southern regions, but its significance diminishes as the thermal resistance of the shell increases. He further uses his length to width ratio formula to produce the least solar irradiation $[\mathrm{L} / \mathrm{W}=$ $(\mathrm{E}+\mathrm{W}) /(\mathrm{N}+\mathrm{S})]$ on buildings with a $1.64: 1$ as a recommendation for Southern USA, e.g. warm and humid Miami. Szokolay (2004) however suggested an aspect ratio of $1: 1.3$ to 2 depending on temperature and radiation.

All the researchers gave clear answers where the orientation of naturally ventilated buildings is of concern. On the other hand, there is not a clear answer to the orientation of airconditioned buildings.

The objective of this study was to use simula- 
tion as a tool to establish a possible relationship between orientation and energy performance of conventional residential buildings in Ghana. The findings of this study, when integrated in our site and community planning, will help in the realisation of efficient and sustainable energy performance of our built environment.

\section{MATERIALS AND METHODS}

To find the optimum direction of orientation and its effect on cooling loads, the application of a dynamic simulation tool, (EDSL 2008) is used to alter the orientation of three typical residential buildings. This software tool dynamically simulates the thermal performance of buildings and their systems. The application creates the sensible heat balance for a zone by setting up equations representing the individual energy balances for the air and each of the surrounding surfaces. These equations are then combined with further equations representing the energy balances at the external surfaces, and the whole equation set is calculated simultaneously to generate air temperatures, surface temperatures and room loads. Conduction in the fabric of the building is treated dynamically, using two methods for the analysis of wall heat flows. For state-representation, finite difference methods are applied whereas conductive heat flows at the surfaces of walls and other building elements are calculated with a response factor method. Convection is treated using a combination of empirical and theoretical relationships. Long-wave radiation exchange is modelled using the Stefan-Boltzmann law. Long-wave radiation from the sky and the ground is treated using empirical relationships (EDSL 2007).

Three residential buildings are used for the simulation analysis with a weather file for $\mathrm{Ku}-$ masi (latitude $6.75^{\circ} \mathrm{N}$ and longitude $-1.58^{\circ} \mathrm{N}$ ), Ghana (Meteotest 2008). The buildings are located in different parts of Kumasi, a two storey square plan house at Suame, a single storey square plan house at Kropo and a single storey rectangular plan house at Bohyen.

The construction technology used in Ghana is a simple artisanship system. The walls are mono- lithic (sandcrete blocks), with a thickness of between 15 and $18 \mathrm{~cm}$. The internal walls are of the same size and composition as the external walls. The floors are usually made of concrete with screed and a terrazzo or tile finish. The ceilings are of wood, either plywood or a tongue and groove panel system on a timber framework. The use of cast plaster of paris panels is on the increase because of the numerous styles made possible through the casting system. The roofs are made of aluminium sheets or clay-tiles on wooden structural system. Windows are either glass louvre blades or sliding windows whereas the doors and frames are of timber

\section{Two storey square plan building at Suame (Kumasi)}

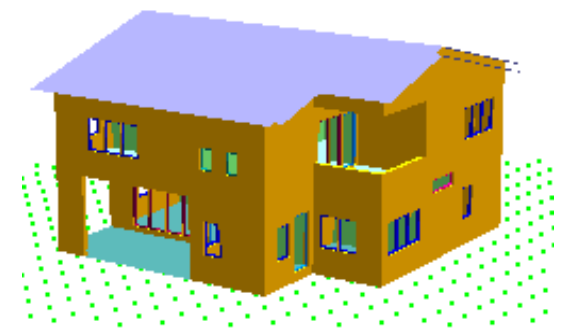

Fig.1: Tas model of building at Suame (Kumasi)

Note: The building was modelled using the Tas $3 D$ Modeller based on measured drawings

The building in Fig.1, has an entrance terrace, living area, dining area, kitchen, storage space and a carport on the ground floor. The first floor has four bedrooms, two sanitary areas and a terrace. The net floor area of the enclosed indoor spaces is $180.64 \mathrm{~m}^{2}$. The height of the building is 8 metres with an assumption of 4.5 metres as the mean height of buildings at the surroundings.

Table 1 shows the composition of the building elements. The window substitute element (curtains) was set to be used between the hours of $9 \mathrm{am}-6 \mathrm{pm}$. 
Table 1: Building element composition/properties of the building at Suame (Kumasi)

\begin{tabular}{lcc}
\hline \multicolumn{1}{c}{ Building element } & $\begin{array}{c}\text { Thickness } \\
(\mathrm{mm})\end{array}$ & $\begin{array}{c}\text { U-Value } \\
\left(\mathrm{W} / \mathrm{m}^{2} \mathrm{C}\right)\end{array}$ \\
\hline Roof [Aluminium sheet-primary purlin-secondary purlin, (lower conductance) $)$ & 280 & 0.661 \\
Door Frame (Timber) & 150 & 1.000 \\
Door Pane (Timber) & 30 & 8.000 \\
External and Internal Walls (plaster-block-plaster) & 190 & 4.310 \\
Ground/Upper Floors (terrazzo-screed-concrete) & 200 & 7.046 \\
Windows (solar transmittance 0.580 and total transmittance 0.678) & 4 & 5.798 \\
Window substitute element (window pane-air layer-curtains) & 204 & 2.700 \\
Ceiling (purlin and plywood) & 70 & 6.986 \\
\hline
\end{tabular}

Source: Construction database of the building designer in Tas (EDSL 2008)

Simulation calendar of the building at Suame (Kumasi)

A standard calendar of Monday to Sunday was selected to run the simulation.

Internal conditions of the building at Suame (Kumasi)

The infiltration rate was set to $0.40 \mathrm{ac} / \mathrm{h}$ (air change per hour), lighting gains $5 \mathrm{w} / \mathrm{m}^{2}$ (watt per square metre), occupancy sensible heat gain $5 \mathrm{w} / \mathrm{m}^{2}$, occupancy latent heat gain $2 \mathrm{w} / \mathrm{m}^{2}$ and equipment sensible heat gain $3 \mathrm{w} / \mathrm{m}^{2}$.
The thermostat was set to start cooling when indoor temperature exceeded $27^{\circ} \mathrm{C}$ and to start heating when room temperatures got below $20^{\circ}$ C.

The building has a $100.61 \mathrm{~m}^{2}$ enclosed floor area and it is $5 \mathrm{~m}$ tall (Fig. 2). It has three bedrooms, living area, dining area, kitchen, storage space and sanitary areas with a front terrace. The overhang is $0.6 \mathrm{~m}$ from the external walls, providing insufficient shading was used for all the cases.

\section{Single storey square plan building at Kropo (Kumasi)}

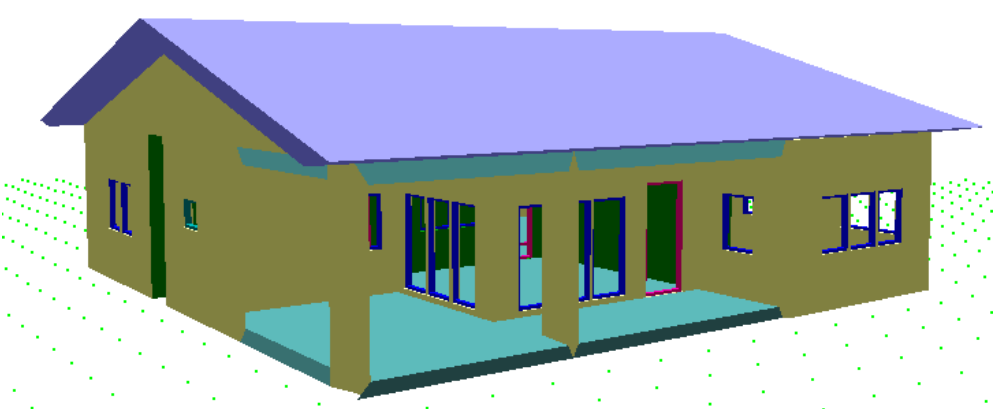

Fig. 2: Tas model of the building (Kropo) from the front

Note: The building was modelled using the Tas 3D Modeller based on measured drawings 
Effects of orientation on energy performance of residential building ...

Table 2: Building element composition/properties of the building at Kropo (Kumasi)

\begin{tabular}{lcc}
\hline \multicolumn{1}{c}{ Building element } & $\begin{array}{c}\text { Thickness } \\
(\mathrm{mm})\end{array}$ & $\begin{array}{c}\text { U-Value } \\
\left(\mathrm{W} / \mathrm{m}^{2} \mathrm{C}\right)\end{array}$ \\
\hline Roof [Aluminium sheet-primary purlin-secondary purlin,(higher conductance) $]$ & 220 & 7.999 \\
Door Frame (Timber) & 150 & 1.000 \\
Door Pane (Timber) & 30 & 8.000 \\
External and Internal Walls (plaster-block-plaster) & 180 & 11.663 \\
Ground (terrazzo, screed and concrete) & 200 & 7.046 \\
Windows (solar transmittance 0.580, light transmittance 0.89 and total trans- & 4 & 5.798 \\
mittance 0.678) & 204 & 2.700 \\
Window substitute element (window pane-air layer-curtains) & 70 & 10.667 \\
Ceiling (purlin and plywood) & & \\
\hline
\end{tabular}

Source: Construction database of the building designer in Tas (EDSL 2008)

Table 2 shows the composition of the building elements. The window substitute element (curtains) was set to be used between the hours of 9 am $-6 \mathrm{pm}$.

\section{Simulation calendar of the building at Kropo (Kumasi):}

A standard calendar of Monday to Sunday was selected to run the simulation.

Internal conditions of the building at Kropo (Kumasi):

The infiltration rate for the major rooms was set to $0.80 \mathrm{ac} / \mathrm{h}$ (air change per hour), lighting gains $5 \mathrm{w} / \mathrm{m}^{2}$ (watt per square metre), occupancy sensible heat gain $5 \mathrm{w} / \mathrm{m}^{2}$, and equipment sensible heat gain $3 \mathrm{w} / \mathrm{m}^{2}$. The infiltration rate for the minor rooms (store and sanitary areas) was set to $0.60 \mathrm{ac} / \mathrm{h}$ (air change per hour), lighting gains $3 \mathrm{w} / \mathrm{m}^{2}$ (watt per square metre), occupancy sensible heat gain $2 \mathrm{w} / \mathrm{m}^{2}$, and equipment sensible heat gain $1 \mathrm{w} / \mathrm{m}^{2}$.

The thermostat was to start cooling when indoor temperature exceeded $27^{\circ} \mathrm{C}$ and to start heating when room temperatures got below $20^{\circ}$ C.

\section{Single storey rectangular plan building at Bohyen (Kumasi)}

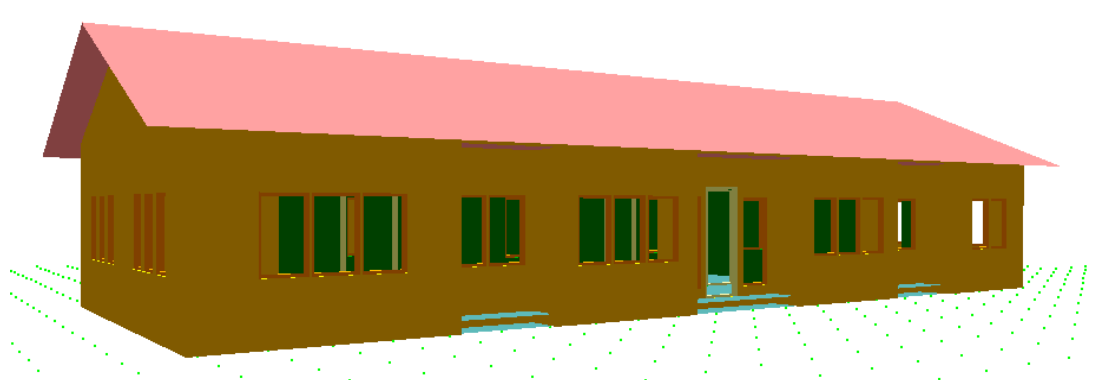

Fig. 3: Tas model of the elongated building at Bohyen (Kumasi)

Note: The building was modelled using the Tas $3 D$ Modeller based on measured drawings 
Table 3: Building element composition/properties of the building at Bohyen (Kumasi)

\begin{tabular}{lcc}
\hline \multicolumn{1}{c}{ Building element } & $\begin{array}{c}\text { Thickness } \\
(\mathrm{mm})\end{array}$ & $\begin{array}{c}\text { U-Value } \\
\left(\mathrm{W} / \mathrm{m}^{2} \mathrm{C}\right)\end{array}$ \\
\hline Roof (Aluminium sheet-primary purlin-secondary purlin) & 220 & 7.999 \\
Door Frame (Timber) & 150 & 1.000 \\
Door Pane (Timber) & 30 & 8.000 \\
External and Internal Walls (plaster-block-plaster) & 200 & 11.663 \\
Ground/Upper Floors (terrazzo, screed and concrete) & 200 & 7.046 \\
Windows (solar transmittance 0.820, light transmittance 0.890 and & 4 & 5.798 \\
total transmittance 0.849 & & 2.700 \\
Window substitute element (window pane-air layer-curtains) & 204 & 10.667 \\
Ceiling (purlin and plywood) & 70 &
\end{tabular}

Source: Construction database of the building designer in Tas (EDSL 2008)

The $137.20 \mathrm{~m}^{2}$ of floor area is $5 \mathrm{~m}$ tall, has three bedrooms, kitchen, dining, storage and an enclosed terrace with a living space. The roof extends $0.60 \mathrm{~m}$ from the external walls to provide insufficient shading.

Table 3 shows the composition of the building elements. The window substitute element (curtains) was set to be used between the hours of $9 \mathrm{am}-6 \mathrm{pm}$.

Simulation calendar of the building at Bohyen (Kumasi):

A standard calendar of Monday to Sunday was selected to run the simulation.

Internal conditions of the building at Bohyen (Kumasi):

(same as previous simulations with the exception of occupancy sensible gain for minor rooms which was set to $3 \mathrm{w} / \mathrm{m}^{2}$ ).

The conductance for some of the building elements and the thicknesses vary in some of the cases e.g., the roof and walls. This is to make the simulation relate to the construction practice in Ghana with the use of different thermal properties for materials. This does not however overrule the aim of trying to find the right orientation for each building type.
The north angle for the simulation was rotated progressively in intervals of $45^{\circ}$ (eg. $0,45,90$, $135,180,225,270$ and 315 degrees) to represent different orientations of the building. For example, a north angle of $90^{\circ}$ represents an orientation towards the east and west.

\section{RESULTS AND DISCUSSION \\ Two storey square plan building at Suame (Kumasi) \\ North Angle at $0^{\circ}$ and $180^{\circ}$}

With the north angle at zero degrees, implying an orientation towards the north and south, the cooling load was $46.92 \mathrm{kWh} \cdot \mathrm{m}^{-2}$ annum $^{-1}$, (kilowatt hours per square metre per annum). However, a heating load of $1.31 \mathrm{kWh} . \mathrm{m}^{-2} \mathrm{a}^{-1}$ was registered. This is insignificant but gives an indication of temperatures falling below $20^{\circ}$ $\mathrm{C}$, triggering heating to maintain comfort.

The weather file shows a minimum temperature of $19^{\circ} \mathrm{C}$ and a maximum of $35^{\circ} \mathrm{C}$. Since the thermostat was set to $20 / 27^{\circ} \mathrm{C}$, there will be some heating below the $20^{\circ} \mathrm{C}$ and cooling above $27^{\circ} \mathrm{C}$. The lower temperatures occur in the chilly mornings of January, during the hamathan and during the rainy season from June/ July through to September/October.

Since the heating loads are low and heating is not an issue in the climatic context of Kumasi, 
Ghana, they will not be discussed. In addition, the usage of heating devices to keep spaces warm for one or two hours in the cooler months cannot be economically justified.

The highest cooling load was recorded in the month of March, $6.42 \mathrm{kWh} . \mathrm{m}^{-2}$ month $^{-1}$ whilst the lowest was in the month of August with $1.18 \mathrm{kWh} \cdot \mathrm{m}^{-2}$ month $^{-1}$. During the same months, $6.31 \mathrm{kWh} . \mathrm{m}^{-2}$, and $1.14 \mathrm{kWh} . \mathrm{m}^{-2}$ were recorded for a north angle of $180^{\circ}$. This shows a minor reduction which could be due to the two terraces on the eastern and western sides of the building on the ground floor, protecting some of the indoor spaces from direct solar radiation (Chou, 2001). Generally, cooling loads were lower during the major rainy season and higher during the first half of the year (see Fig. 4). This was due to the lower and higher conductive gains as an effect of the mean outdoor temperatures during the rainy season and in the months from February to May respectively (Meteotest, 2008).
North Angle at $45^{\circ}$ and $225^{\circ}$

The cooling load recorded was $46.28 \mathrm{kWh} . \mathrm{m}^{-2} \mathrm{a}$ ${ }^{-1}$ with the peak recording of $6.44 \mathrm{kWh} \cdot \mathrm{m}^{-2}$ in March and the lowest load of $1.13 \mathrm{kWh} \cdot \mathrm{m}^{-2}$ in August. This shows a slight decrease of 0.64 $\mathrm{kWh} \cdot \mathrm{m}^{-2} \mathrm{month}^{-1}$ compared to the north angle of zero degrees (Fig. 5). A further decrease of $0.17 \mathrm{kWh} \cdot \mathrm{m}^{-2} \mathrm{a}^{-1}$ was recorded at a north angle of $225^{\circ}$. This gives an indication that the composition of the spaces has a relationship to orientation and also cooling loads (Givoni, 1981). In a similar study, Prajapati (2006), recorded up to $8 \%$ reduction of cooling loads in north-south and northeast-southwest orientations.

\section{North Angle at $90^{\circ}$ and $270^{\circ}$}

At a north angle of $90^{\circ}$, a cooling load of 45.41 $\mathrm{kWh} \cdot \mathrm{m}^{-2} \mathrm{a}^{-1}$ was recorded as compared to 46.58 $\mathrm{kWh} \cdot \mathrm{m}^{-2} \mathrm{a}^{-1}$ for $270^{\circ}$. Although at $270^{\circ}$, the load was $1.17 \mathrm{kWh} \cdot \mathrm{m}^{-2} \mathrm{a}^{-1}$ higher, this was still low as it was anticipated that with the intense solar radiation from the eastern and western sides, much higher cooling loads would be recorded.

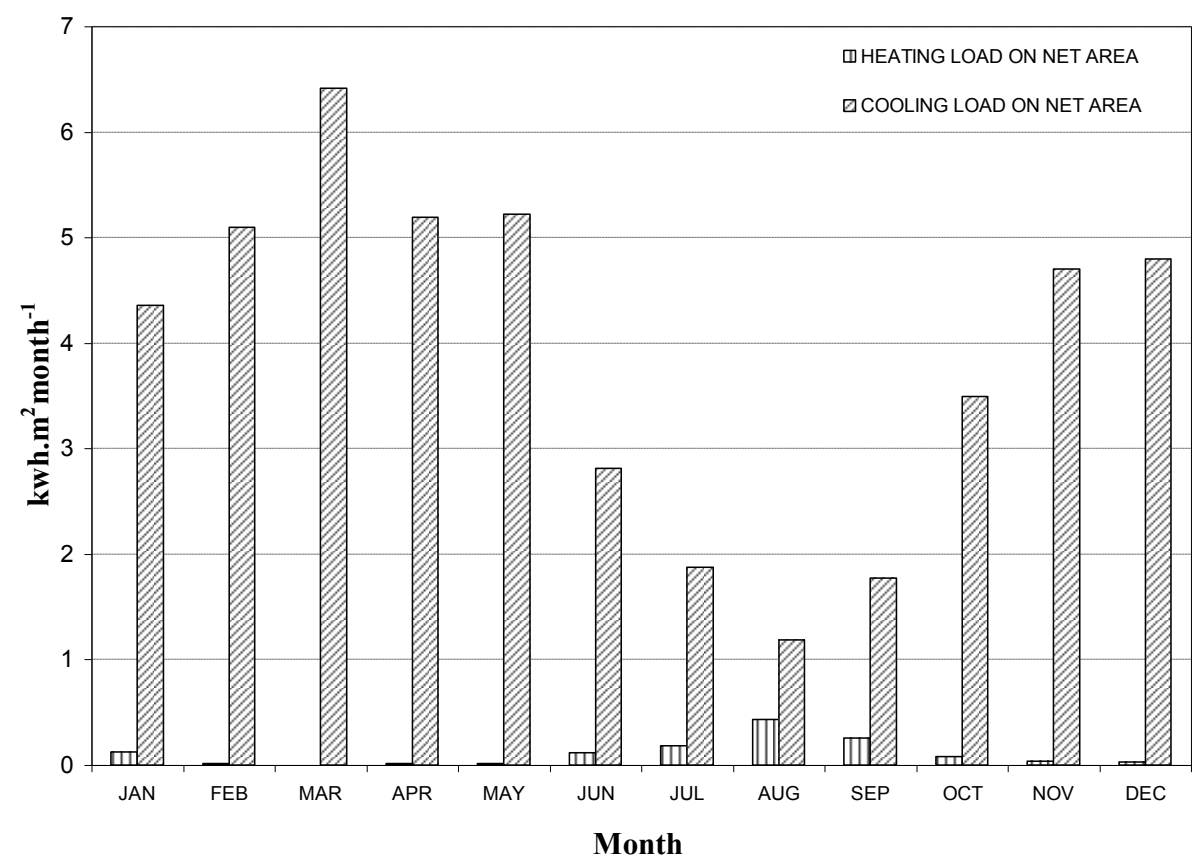

Fig.4: Monthly cooling and heating loads (two storey square plan building) per area at north angle of $0^{\circ}$ 


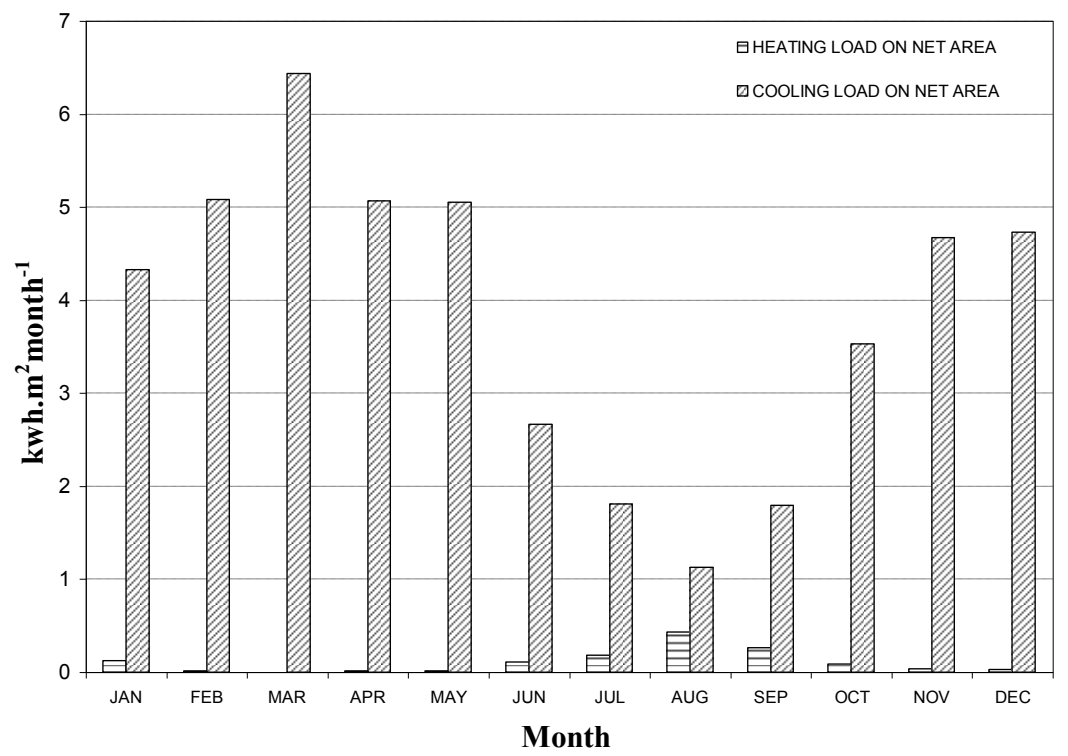

Fig. 5: Monthly cooling and heating loads (two storey square plan building) per area at north angle of $45^{\circ}$ north orientation

The relatively low cooling load was not expected and indicates that thermal mass, and eventually orientation, also have an effect on cooling loads (Hawkes, 1996).
North Angle at $135^{\circ}$ and $315^{\circ}$

The above north angles registered 45.63 and $47.28 \mathrm{kWh} \cdot \mathrm{m}^{-2} \mathrm{a}^{-1}$ respectively. This shows the highest difference in cooling loads of 1.65

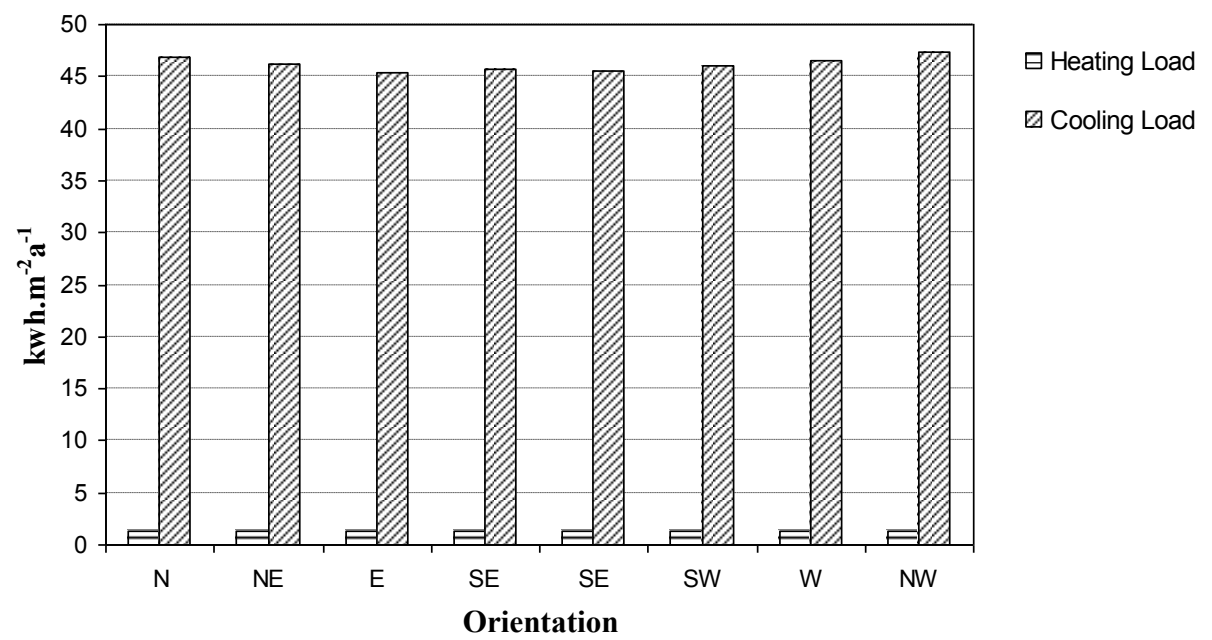

Fig. 6: Annual cooling and heating loads (two storey square plan building) per area at different north orientation angles 
$\mathrm{kWh} \cdot \mathrm{m}^{-2} \mathrm{a}^{-1}$ compared to the other pairs of north angles. Whilst there was a reduction of 22 $\mathrm{kWh} . \mathrm{m}^{-2} \mathrm{a}^{-1}$ from $90^{\circ}$ north angle to $135^{\circ}$ north angle, there was a very slight increase of 0.7 $\mathrm{kWh} . \mathrm{m}^{-2} \mathrm{a}^{-1}$ from $270^{\circ}$ north angle to $315^{\circ}$ north angles.

Summary of results on the two storey square plan building at Suame (Kumasi)

Although there are differences in the cooling loads, they seem to be minor and therefore insignificant (Fig. 6). The maximum cooling load was recorded at a north angle of $315^{\circ}$ and the minimum at a north angle of $90^{\circ}$. The average cooling load over all the different orientations was $46.51 \mathrm{kWh} \cdot \mathrm{m}^{-2} \mathrm{a}^{-1}$ with a standard deviation of 0.69 . This shows how compressed the loads are and therefore, one cannot confidently propose an ideal orientation for the above case study.

The order of preferred north angle orientation in Table 4, suggests an orientation towards the east/west as most preferred, followed by north/ south, northeast/southwest and the most unpreferred orientation of southwest/northeast $\left(315^{\circ}\right)$. This order shows an increase in cooling loads of $0.13 \%, 0.48 \%$ and $4.12 \%$ relative to the lowest cooling load (at north angle of $90^{\circ}$ ) of $45.41 \mathrm{kWh} \cdot \mathrm{m}^{-2} \mathrm{a}^{-1}$.

This finding seems to confirm what some of the researchers, Lechner (2001), Hawkes (1996) and Givoni (1981), who are of the opinion that with air-conditioned buildings, exact orienta- tion is not the issue, but rather other design parameters.

\section{Single storey square plan building at Kropo (Kumasi) \\ North Angle at $0^{\circ}$ and $180^{\circ}$}

The monthly cooling loads are higher in the months from February to May; because the outdoor temperatures and conductive gains are also higher. The peak is in the month of March with a recording of $1.98 \mathrm{kWh} \cdot \mathrm{m}^{-2} \mathrm{month}^{-1}$. Cooling loads in the months from July to September are minimal and insignificant (Fig. 7). The building could run in passive mode or be supported with fans to keep the indoor climate in a comfortable range (Hyde, 2000). The annual cooling load of $8.99 \mathrm{kWh} . \mathrm{m}^{-2}$ is 1.28 $\mathrm{kWh} \cdot \mathrm{m}^{-2}$ less than when the north angle is at $180^{\circ}$.

\section{North Angle at $45^{\circ}$ and $225^{\circ}$}

At a north angle orientation of $45^{\circ}$, the cooling load of $8.99 \mathrm{kWh} \cdot \mathrm{m}^{-2} \mathrm{a}^{-1}$ remained unchanged. However, at $225^{\circ}$, the cooling load recorded was $9.93 \mathrm{kWh} \cdot \mathrm{m}^{-2} \mathrm{a}^{-1}$ and this shows a difference of $0.94 \mathrm{kWh} \cdot \mathrm{m}^{-2} \mathrm{a}^{-1}$. This difference could be due to the composition of the spaces since the northern side was composed of closed spaces with exposed walls whilst the southern side has more recessed unexposed walls due to the terrace.

\section{North Angle at $90^{\circ}$ and $270^{\circ}$}

At both angles, a difference of $0.17 \mathrm{kWh} \cdot \mathrm{m}^{-2} \mathrm{a}^{-1}$ was recorded with a minimum at the north an-

Table 4: Rank of preferred north angle orientation (with 1 being the most and 8 the least preferred orientation) on the two storey square plan building

\begin{tabular}{cccc}
\hline Rank & $\begin{array}{c}\text { North angles } \\
\left({ }^{\circ}\right)\end{array}$ & $\begin{array}{c}\text { Cooling loads } \\
\left(\mathbf{k W h . m}^{-2} \mathbf{a}^{-\mathbf{1}}\right)\end{array}$ & $\begin{array}{c}\text { Change relative to lowest } \\
\text { cooling loads (\%) }\end{array}$ \\
\hline 1 & 90 & 45.41 & - \\
2 & 180 & 45.47 & 0.13 \\
3 & 135 & 45.63 & 0.48 \\
4 & 225 & 46.11 & 1.54 \\
5 & 45 & 46.28 & 1.92 \\
6 & 270 & 46.58 & 2.58 \\
7 & 0 & 46.92 & 3.33 \\
8 & 315 & 47.28 & 4.12 \\
\hline
\end{tabular}


gle of $90^{\circ}\left(8.93 \mathrm{kWh} \cdot \mathrm{m}^{-2} \mathrm{a}^{-1}\right)$ and a maximum at $270^{\circ}$ with a cooling load of $9.1 \mathrm{kWh} \cdot \mathrm{m}^{-2} \mathrm{a}^{-1}$. This shows the minimum difference in the pairs of the north angle orientations.

North Angle at $135^{\circ}$ and $315^{\circ}$

The north angle at $135^{\circ}$ resulted in a cooling load of $9.97 \mathrm{kWh} . \mathrm{m}^{-2} \mathrm{a}^{-1}$ and $9.31 \mathrm{kWh} \cdot \mathrm{m}^{-2} \mathrm{a}^{-1}$ from the $315^{\circ}$ north angle. All the differences in the pairs are in the range of less than one $\left(\mathrm{kWh} \cdot \mathrm{m}^{-2} \mathrm{a}^{-1}\right)$ with the exception of $0^{\circ} / 180^{\circ}$ north angle. Though it is obvious that the spatial composition, shading and thermal mass seem to play a role, they however do not result in a massive difference in cooling load (Salmon 1999).

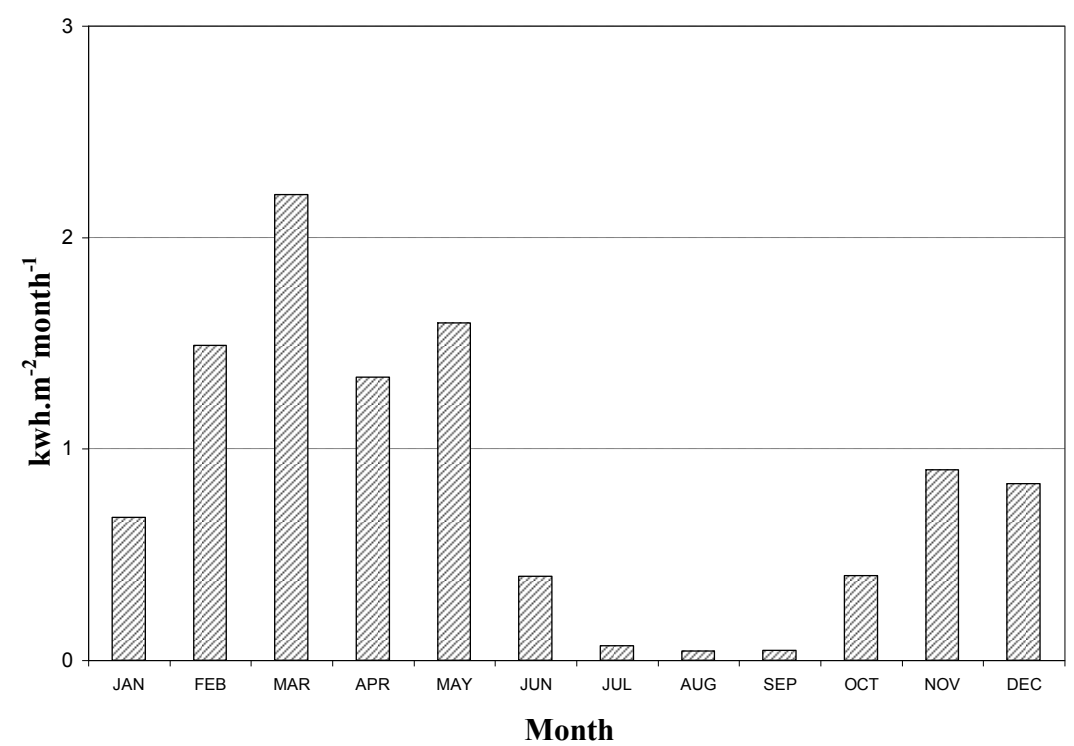

Fig. 7: Monthly cooling loads (single storey square plan building) per area at $0^{\circ}$ north orientation.

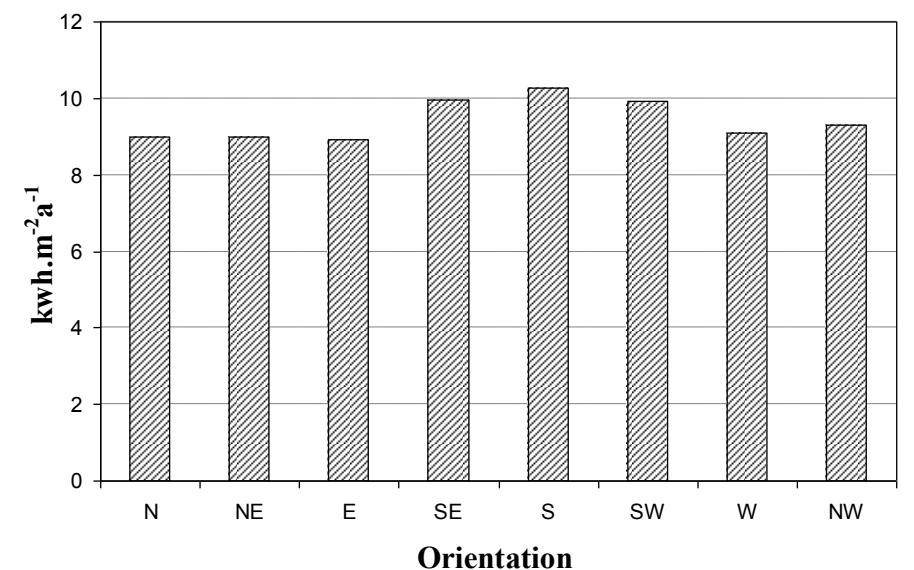

Fig.8: Annual cooling loads (single storey square plan building) per area at different north orientation angles 
Summary of results on the single storey square plan building at Kropo (Kumasi)

From Fig.8, a desired north orientation of $0^{\circ}$, $45^{\circ}$, and $90^{\circ}$ results in minimum cooling loads (Prajapati, 2006). The maximum loads are at a north orientation of $180^{\circ}, 135^{\circ}$ and $225^{\circ}$. The maximum load is $10.27 \mathrm{kWh} \cdot \mathrm{m}^{-2} \mathrm{a}^{-1}$ and the minimum load is $8.93 \mathrm{kWh} \cdot \mathrm{m}^{-2} \mathrm{a}^{-1}$. The average cooling load of $9.44 \mathrm{kWh} \cdot \mathrm{m}^{-2} \mathrm{a}^{-1}$ and a standard deviation of 0.54 shows the closeness of the loads.
From Table 5, the preferred north angle orientation will be in the following order $90^{\circ}, 0^{\circ}$ and lastly $180^{\circ}$. The second and last preferred orientations give the impression of how spatial composition can affect cooling loads. A study of the building shows that if spaces and windows are recessed and protected from direct solar radiation, cooling loads tend to reduce (Heerwagen, 2004). This design principle, if adhered to, could significantly reduce cooling loads (Kiang et al. 2000).

Table 5: Rank of preferred north angle orientation (with 1 being the most and 8 the least preferred orientation) on the single storey square plan building

\begin{tabular}{cccc}
\hline Rank & $\begin{array}{c}\text { North angles } \\
\left(\boldsymbol{(}^{\mathbf{C}}\right.\end{array}$ & $\begin{array}{c}\text { Cooling loads } \\
\left(\mathbf{k W h} \mathbf{m}^{-\mathbf{2}} \mathbf{a}^{\mathbf{1}}\right)\end{array}$ & $\begin{array}{c}\text { Change relative to lowest } \\
\text { cooling loads (\%) }\end{array}$ \\
\hline 1 & 90 & 8.93 & - \\
2 & 0 & 8.99 & 0.67 \\
3 & 45 & 8.99 & 0.67 \\
4 & 270 & 9.10 & 1.90 \\
5 & 315 & 9.31 & 4.26 \\
6 & 225 & 9.93 & 11.20 \\
7 & 135 & 9.97 & 11.65 \\
8 & 180 & 10.27 & 15.01 \\
\hline
\end{tabular}

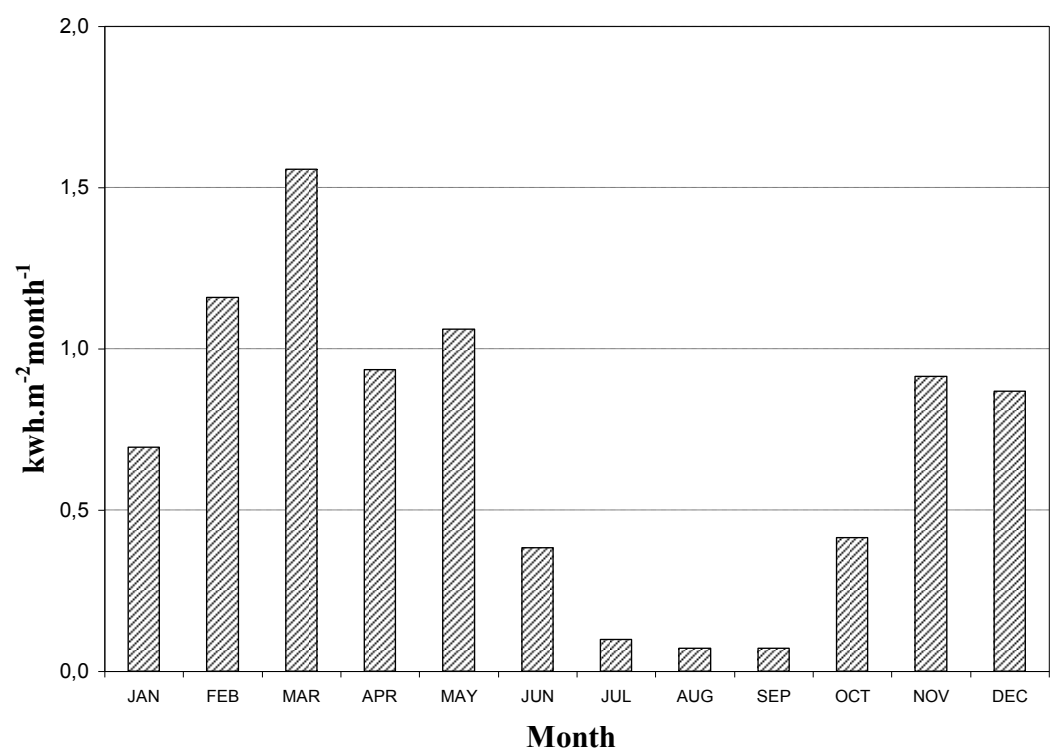

Fig. 9: Monthly cooling loads (single storey rectangular plan building) per area at $0^{\circ}$ north angle orientation. 
Single storey rectangular plan building at Bohyen (Kumasi)

North Angle at $0^{\circ}$ and $180^{\circ}$

The month of March records the highest cooling load and in August/September we have seen the minimum load in all the case studies. A cooling load of $1.56 \mathrm{kWh} \cdot \mathrm{m}^{-2}$ month $^{-1}$ was recorded in March and $0.07 \mathrm{kWh} . \mathrm{m}^{-2}$ month $^{-1}$ in the months of August and September. July recorded $0.10 \mathrm{kWh} . \mathrm{m}^{-2}$ month $^{-1}$ with a slight increase in loads for June and October (Fig. 9). During the major rainy season, the building could run in passive mode supported with the use of fans. This will be a lower energy consumption option for buildings (Heerwagen, 2004).

The annual cooling load recorded was 8.23 $\mathrm{kWh} . \mathrm{m}^{-2} \mathrm{a}^{-1}$ at a north angle of $0^{\circ}$. Comparatively, at a north angle of $180^{\circ}$, a cooling load of $8.68 \mathrm{kWh} . \mathrm{m}^{-2} \mathrm{a}^{-1}$ was recorded. This shows a difference of $0.45 \mathrm{kWh} \cdot \mathrm{m}^{-2} \mathrm{a}^{-1}$. This difference was achieved through a recess of the bedrooms away from the southern sun, causing lower consumptions in energy (Kiang et al., 2000). The authors as well as most researchers such as Szokolay (2004), Heerwagen (2004) and
Givoni (1981) recommend this design principle. Lauber (2005) also supports this sustainable measure.

\section{North Angle at $45^{\circ}$ and $225^{\circ}$}

At the $45^{\circ}$ north angle, the cooling load amounted to $9.18 \mathrm{kWh} \cdot \mathrm{m}^{-2} \mathrm{a}^{-1}$ and $9.38 \mathrm{kWh} . \mathrm{m}^{-}$ ${ }^{2} \mathrm{a}^{-1}$ at an angle of $225^{\circ}$. The difference of 0.2 $\mathrm{kWh} . \mathrm{m}^{-2} \mathrm{a}^{-1}$ is insignificant. This orientation cannot be recommended since the loads are higher than the $0^{\circ}$ north angle.

\section{North Angle at $90^{\circ}$ and $270^{\circ}$}

Monthly cooling loads were generally higher at $270^{\circ}$ north angle with a peak in March at 1.82 $\mathrm{kWh} . \mathrm{m}^{-2}$ month $^{-1}$ and minimum of $0.05 \mathrm{kWh} . \mathrm{m}^{-}$ ${ }^{2}$ month $^{-1}$ during the months of August and September (Fig. 10). The annual cooling load of $8.96 \mathrm{kWh} \cdot \mathrm{m}^{-2} \mathrm{a}^{-1}$ at $90^{\circ}$ north angle was 0.84 $\mathrm{kWh} . \mathrm{m}^{-2} \mathrm{a}^{-1}$ lower than the orientation towards the $270^{\circ}\left(9.8 \mathrm{kWh} \cdot \mathrm{m}^{-2} \mathrm{a}^{-1}\right)$. This shows a difference in load of $1.57 \mathrm{kWh} . \mathrm{m}^{-2} \mathrm{a}^{-1}$ between the $0^{\circ}$ north angle and the $270^{\circ}$ north angles.

\section{North Angle at $135^{\circ}$ and $315^{\circ}$}

The second highest cooling load difference (0.6 $\left.\mathrm{kWh} \cdot \mathrm{m}^{-2} \mathrm{a}^{-1}\right)$ in the pairs of north angle orienta-

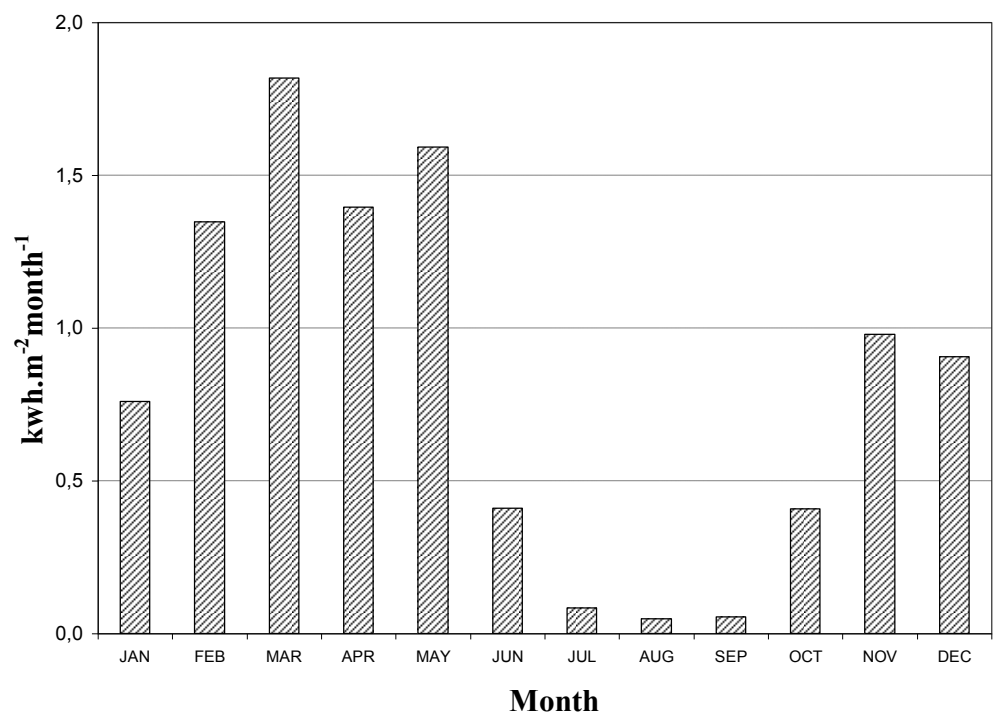

Fig.10: Monthly cooling loads (single storey rectangular plan building) per area at $270^{\circ}$ north angle orientation 
tions was recorded at north angles $135^{\circ}$ and $315^{\circ}$. The lower of the two was at $135^{\circ}$, and this seemed to buttress the effect of shading more building mass from solar radiation and thereby having a positive effect on cooling loads (Chou 2001). A load of $9.52 \mathrm{kWh} \cdot \mathrm{m}^{-2} \mathrm{a}^{-1}$ was recorded at a north angle of $315^{\circ}$.

\section{Summary of results on the rectangular building at Bohyen (Kumasi)}

For rectangular/elongated buildings, an orientation to the north and south can be recommended since the lowest cooling loads were recorded at both corresponding north angles
(Fig. 11), (Wagner et al. 1980). An increase of $5.47 \%$ was recorded at a north angle of $180^{\circ}$ and this could be due to the effect of direct and indirect solar radiation on the building mass. If the building had been oriented towards a north angle of $135^{\circ}(\mathrm{SE})$, an increase of $8.38 \%$ cooling load would have been recorded. At a north angle of $270^{\circ}$, the increase in cooling loads relative to the lowest at $0^{\circ}$ was $19 \%$ (Table 6 ).

Among other factors, all the increases were due to the fact that a large area at the eastern and western sides of the building fabric was exposed to intense solar radiation. The view that

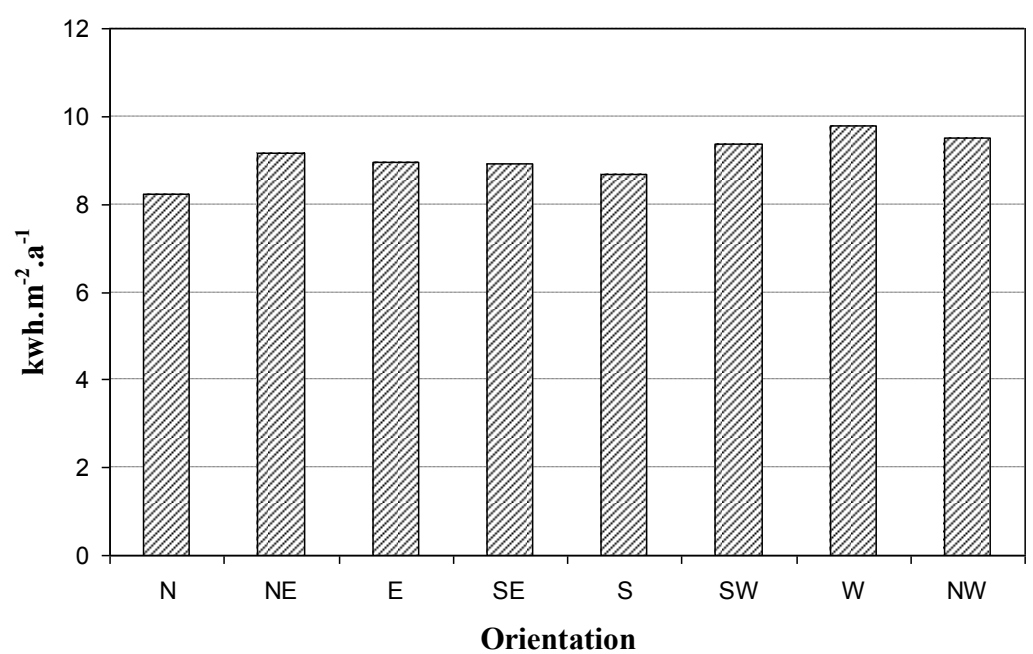

Fig.11: Annual cooling loads (single storey rectangular building) per area at different north orientation angles

Table 6: Rank of preferred north angle orientation (with 1 being the most and 8 the least preferred orientation) on the single storey rectangular building

\begin{tabular}{|c|c|c|c|}
\hline Rank & $\begin{array}{c}\text { North angles } \\
\left(^{\circ}\right)\end{array}$ & $\begin{array}{l}\text { Cooling loads } \\
\left(\mathrm{kWh} \cdot \mathrm{m}^{-2} \mathrm{a}^{-1}\right)\end{array}$ & $\begin{array}{c}\text { Change relative to lowest cooling } \\
\text { loads }(\%)\end{array}$ \\
\hline 1 & 0 & 8.23 & - \\
\hline 2 & 180 & 8.68 & 5.47 \\
\hline 3 & 135 & 8.92 & 8.38 \\
\hline 4 & 90 & 8.96 & 8.87 \\
\hline 5 & 45 & 9.18 & 11.54 \\
\hline 6 & 225 & 9.38 & 13.97 \\
\hline 7 & 315 & 9.52 & 15.67 \\
\hline 8 & 270 & 9.8 & 19.08 \\
\hline
\end{tabular}


this practice is not to be recommended is shared by Szokolay (2004), Givoni (1981) and Lauber (2005).

\section{CONCLUSION}

The use of simulation as a tool in finding and recommending the right orientation for conventional buildings in Ghana helped to show the different cooling loads when buildings are oriented differently. It also showed the importance of considering other design parameters in architectural design. This is seen in the results for the two storey and single storey square residential buildings, where not all the pairs of the north angle orientation could be confidently recommended, even though a north angle of $90^{\circ}$ for example showed the least cooling loads. On the rectangular building, the north angle of $0^{\circ}$ and $180^{\circ}$ is confidently recommended, since both angle pairs recorded the lowest cooling loads. For buildings to be energy efficient, simulation must be used to try out design alternatives of the different design parameters in the early stages of design. Other design parameters such as configuration of spaces, function, shading and passive design methods, must be promoted for an environmentally sound tropical architecture for residential buildings in Ghana.

\section{REFERENCES}

Chou, S.K. (2001). Seminar Proceedings, Energy Efficiency in Building Design: Building Energy Standard, Building and Construction Authority of Singapore, Singapore (18 ${ }^{\text {th }}$ April 2001), paper 2.

EDSL, (2007). A-TAS Theory Manual. EDSL Documentation, www.edsl.net.

EDSL, (2008). A-TAS Version 8.5, Environmental Design Solutions Limited, www.edsl.net.

Ferstl, K.J. (2003). Workshop Proceedings, Energy Conserving Concepts in Building Design and Construction, Cooling your Home Naturally, Accra/Ghana (3 $3^{\text {rd }}$ to $7^{\text {th }}$ November 2003).
Givoni, B. (1981). Man, Climate and Architecture, Second Edition, Van Nostrand Reinhold Company, New York., pp 213 - 231.

Gut P. and Ackerknecht D. (1993). Climate Responsive Building, First Edition, SKAT - Swiss Centre for Development and Cooperation in Technology and Management, Switzerland, pp 161 - 170.

Hawkes, D. (1996). The Environmental Tradition - Studies in the Architecture of Environment, E and FN SPON, London, pp 36 45.

Heerwagen, D. (2004). Passive and Active Environmental Controls: Informing the Schematic Designing of Buildings, First Edition, McGraw Hill, New York, USA.

Hyde, R. (2000). Climate Responsive Design, First Edition, E \& FN Spon, United Kingdom, pp 76.

Kiang, P.S., Feriadi, H., Biao, W.J. and Batia, S. (2000). Evaluation of Energy Performance Using Doe-2 Energy Simulation Programme in Singapore, Dimensi Teknik Arsitektur, 28(2), 147 - 154.

Koenigsberger, O.H., Ingersoll, T.G., Mayhew, A. and Szokolay, S.V. (1974). Manual of Tropical Housing and Building: Part One, Climatic Design, First Edition, Longman Inc., New York, pp 216.

Lauber, W. (2005). Tropical Architecture, First Edition, Prestel Verlag, Munich., pp 9, 101 $-105$.

Lechner, N. (2001). Heating, Cooling, Lighting: Design Methods for Architects, Second Edition, John Wiley and Sons, Inc., New York.

Meteotest, (2008). Meteonorm Version 6.0, www.meteotest.ch.

Prajapati, J. (2006). Workshop Proceedings, Design Guidelines for Energy Efficient Buildings, Department of Energy Science and Engineering, Indian Institute of Technology, Bombay, (September 2006), pp 12 $-21$. 
Effects of orientation on energy performance of residential building ... 101

Salmon, C. (1999). Architectural Design for Tropical Regions, First Edition, John Wiley and Sons, Inc., New York, pp 124 125.

Stein, B. and Reynolds, J.S. (2000). Mechanical and Electrical Equipment for Buildings, Ninth Edition, John Wiley and Sons Inc, New York, Page 195, 196, 220 and 224.

Szokolay, S. (2004). Introduction to Architectural Science: The Basis of Sustainable Design, First Edition, Architectural Press, Oxford, pp 68 - 70.
Wagner, W., Robinson, J. and Markert, P. (1980). Energy-Efficient Buildings, First Edition, McGraw-Hill Book Company, New York, USA, pp 8.

Watson, D. and Labs, K. (1983). Climatic Design: Energy-Efficient Building Principles and Practices, First Edition, McGraw-Hill Book Company, New York, pp 52, 107. 